\title{
Routine intracranial pressure monitoring in a countryside university hospital
}

\author{
Andrei Ferraz, Gerson Luiz de Macedo, Wiliam Faviere
}

Divisão de Neurocirurgia do Serviço de Clínica Cirúrgica e Serviço de Terapia Intensiva. Hospital Universitário Sul Fluminense, Vassouras, RJ

\section{ABSTRACT}

Intracranial pressure monitoring has become critical for the adequate management of patients with severe head injury in recent years. Several other recommendations for intracranial pressure monitoring have also been described, specially for patients with subarachnoid hemorrhage with ventricular enlargement, and spontaneous intracerebral hematomas. The immediate postoperative period of elective surgeries that require brain retraction is another instance where intracranial pressure monitoring could provide useful informations to optimize outcome. Expensive methods make it almost prohibitive to smaller centers in our Country.

We describe our protocol of routine intracranial pressure monitoring using an intraventricular catheter connected to an external strain gauge transducer adapted to an ordinary invasive pressure monitor, in a countryside university hospital, and analyze the data of intracranial pressure and cerebral perfusion pressure obtained with regards to outcome and also investigate the more common complications of the method.

We conclude that intracranial pressure monitoring could be safely applied at a low cost to improve the management of those patients.

\section{KEYWORDS}

Critical care. Routine intracranial pressure monitoring.

\section{RESUMO}

Monitorização da pressão intracraniana de rotina em hospital universitário rural A monitorização da pressão intracraniana tornou-se crítica para o manuseio adequado de pacientes com trauma craniencefálico grave nos últimos anos. Diversas outras recomendações para monitorização da pressão intracraniana também foram descritas, especialmente para pacientes com hemorragia subaracnóidea com dilatação ventricular e hematomas intracerebrais espontâneos. O período pós-operatório imediato de cirurgias eletivas que necessitem de retração cerebral é outro exemplo em que essa monitorização pode fornecer informações importantes para otimizar o resultado final. Métodos caros tornam a monitorização da pressão intracraniana proibitiva para centros menores em nosso país que tratam deste tipo de paciente.

Nós descrevemos nosso protocolo de monitorização da pressão intracraniana de rotina utilizando um cateter intraventricular conectado a um transdutor de pressão externo adaptado a um monitor de pressão invasiva usual em um hospital universitário em zona rural. Analisamos os dados de pressão intracraniana e pressão de perfusão cerebral obtidos em relação à evolução e investigamos as complicações do método.

Concluímos que a monitorização de pressão intracraniana pode ser realizada de maneira segura, a baixo custo, para melhorar o manuseio desses pacientes.

\section{PALAVRAS-CHAVE}

Monitorização da pressão intracraniana. Terapia intensiva. 


\section{Introduction}

Great emphasis has been placed in the last years on the possibility of secondary insults in patients with brain damage, even under intensive care treatment, leading to an unfavorable outcome. Intracranial pressure (ICP) monitoring has taken part in the diagnostic and therapeutic arsenal to detect and treat patients with conditions that disturb normal ICP and cerebral perfusion pressure (CPP). Marmarou et al. ${ }^{27}$ were one of the first investigators to consistently describe the influence of intracranial hypertension and systemic hypotension, which ultimately modify the CPP, on the negative outcome of patients with severe head injury. Several protocols have been published since, focusing on ICP control and CPP enhancement, most of them based on what can be called a "head trauma model"1,2,19,20,25,26,32,33,34,37,43,44. Less information is available regarding the management of patients with non-traumatic disorders that can potentially raise ICP and also regarding the patients in the immediate postoperative period of elective surgeries for pathologies that require brain retraction $^{5,6,10,12,15,22,29,31,35,45}$. Nonetheless, ICP monitoring has been widely used for all these purposes. Another clear advantage of this usage is the reduction in unnecessary and potentially hazardous therapeutic tools for patients under controlled ICP, such as hyperventilation, osmotic diuresis and prolonged sedation ${ }^{19,20,26}$. On the other hand, expensive equipment such as highfidelity fiberoptic devices could be required which often make it not viable to most of the hospitals in our Country.

The recently published Guidelines for the Management of Severe Head Injury has renewed our interest to routinely monitor our patients with intracranial lesions under some specific conditions utilizing an intraventricular catheter connected to an ordinary invasive pressure monitor ${ }^{19,20,43}$. It is not our purpose to test the reliability of this method, which has been done elsewhere ${ }^{19,39,41,43}$ but rather to investigate the feasibility to perform it under a routine basis in a countryside hospital in order to stimulate its more widespread usage.

\section{Clinical material and methods}

Twenty patients admitted to the Intensive Care Unit (ICU) between March 2000 and July 2001 underwent intracranial pressure monitoring and were therefore included in the study. They were further divided into an elective ICP monitoring group (Group $1 ; \mathrm{n}=6,30 \%$ ) and an emergency ICP monitoring group (Group 2; $\mathrm{n}=14,70 \%$ ).

In all patients an intraventricular catheter was placed in the frontal horn of the lateral ventricle ipsilateral to the lesion or on the right side in diffuse lesions. An incision was made with a scalpel to the tip of the catheter along one of the rows of fenestrations so that the guide could be placed outside it in order to easily detect any CSF outflow and reduce the need for repeated punctures. The method of insertion is described elsewhere ${ }^{13}$. The catheter was, then, connected to a three-way stopcock device with a disposable dome membrane (Novatrans Dome MX848; Medex Inc., Dublin, Ohio, USA) which is coupled to an external pressure transducer (MX 860; Medex Inc.) linked to an invasive pressure monitor (Biomonitor 7 - IPX0; Bese, Belo Horizonte, MG, Brasil) on one side, and to an external closed collector system on the other side. Mean intracranial pressure was displayed alongside its wave. The monitor was settled to record the last 12 hours ICP variation curve. CSF was drained whenever ICP exceeded $20 \mathrm{mmHg}$ for at least 5 minutes to exclude any manipulation artifacts. The patients were maintained under sedation with midazolan dripping and, occasionally, intermittent phentanyl during the monitoring period so that respiratory parameters could be kept within desired values. The monitor was recalibrated whenever the patient head was repositioned. Every ICP reading that was not accompanied by its wave was considered artifactual and discarded; the system was checked for CSF draining and the catheter was repositioned as needed. We focused on keeping CPP over $70 \mathrm{mmHg}$, although we did not deliberately use any measures to specifically raise it other than the ICP control and volume expansion and/ or vasopressors needed to stabilize the patient's hemodynamics. Arterial blood gases and hemograms were recorded and documented as daily averages. Ventilatory parameters were managed to maintain $\mathrm{SatO} 2$ between $95-100 \%$ and $\mathrm{PaCO} 2$ initially around $35-40$ $\mathrm{mmHg}$. In patients with ICP that could not be controlled by repeated CSF draining, mannitol was added in doses of 0.25 to $0.5 \mathrm{~g} / \mathrm{kg}$ every four hours; hyperventilation was then instituted, with a $\mathrm{PaCO} 2$ goal of never less than $25 \mathrm{mmHg}$. These measures were initiated in a stepwise fashion. No mannitol or hyperventilation were used if ICP was normal or could be controlled by CSF draining alone and they were always tapered off if ICP returned to satisfactory values.

The data of the patients studied in this report are shown in table 1. Patients operated on for pathologies that required brain retraction were kept under general anesthesia to the end of the procedure and taken to the ICU with a ventricular catheter in place to be monitored. No mannitol administration or hyperventilation were done on a regular basis. Those patients comprise the elective ICP monitoring group (Group 1). 
In the emergency ICP monitoring group (Group 2) all patients with a post-resuscitation Glasgow Coma Scale (GCS) score of 8 or less with abnormality on the CT scan or cerebral angiography (if a CT scan was not available) underwent endotracheal intubation and taken to the operating theater, if needed, and then to the ICU to be monitored. Patients with a GCS score of 8 or less and no radiological abnormality were monitored if they had at least two out of three criteria: a) abnormal posturing; b) admission systolic pressure $£ 90 \mathrm{mmHg}$; c) age over 40 years. Mannitol was administered empirically before the ventriculostomy was performed if the patient neurological condition deteriorates at least 2 points in the GCS or if presents signs of acute brain herniation.

The ICP monitoring was removed when the ICP persisted for at least 24 hours under $20 \mathrm{mmHg}$ without the need for CSF drainage. We initially established that if ventriculitis develops the catheter would also be removed.

A Glasgow Outcome Scale (GOS) of 1-2 was defined as bad outcome, while a GOS of 3-5 was defined as good outcome.

Data regarding initial and average ICP and CPP readings, pupillary asymmetry, neurological deterioration, pathological waveforms, complications and outcome were registered and plotted in a spreadsheet for further analysis. They are presented as mean \pm standard deviation when appropriate. Comparisons were computed with Student's t-test and Fisher's exact test with the assistance of a commercially available software (InStat 3.05 for Windows; GraphPad Software Inc., San Diego, California, USA).

\section{Results}

\section{ICP, CPP readings and outcome}

We were able to place the catheter in the proposed frontal horn in all cases in this series. Moreover, we noted an evident learning curve towards the last ten patients who rarely needed more than one successful puncture, even in cases with severe diffuse swelling and a slit ventricle. Patients were monitored for a mean period of $3.6 \pm 2.5$ (range 1-11) days; their age varied from $8-65$ years (mean $38.1 \pm 15.9)$. There were 9 women $(45 \%)$ and 11 men $(55 \%)$ (Tables 1 and 2$)$.

\begin{tabular}{|c|c|c|c|c|c|c|c|}
\hline \multicolumn{8}{|c|}{$\begin{array}{c}\text { Table } 1 \\
\text { Clinical data of monitored patients* }\end{array}$} \\
\hline Case & Age/Sex & Diagnosis & $\begin{array}{c}\text { Initial GCS } \\
\text { Score } \\
\end{array}$ & $\begin{array}{c}\text { Initial ICP } \\
(\mathrm{mmHg})\end{array}$ & $\begin{array}{c}\text { Initial CPP } \\
(\mathrm{mmHg})\end{array}$ & $\begin{array}{c}\text { Pupillary } \\
\text { asymmetry }\end{array}$ & $\begin{array}{l}\text { Neurological } \\
\text { deterioration }\end{array}$ \\
\hline \multicolumn{8}{|l|}{ Group $1 \dagger$} \\
\hline 1 & $49, \mathrm{~F}$ & ACoA aneurysm & 15 & 9 & 101 & NA & NA \\
\hline 2 & $43, \mathrm{M}$ & ACoA aneurysm & 14 & 8 & 112 & NA & NA \\
\hline 3 & $48, \mathrm{~F}$ & ICAbif aneurysm & 15 & 12 & 94 & NA & NA \\
\hline 4 & $50, \mathrm{~F}$ & Parafalcine meningioma & 15 & 7 & 103 & NA & NA \\
\hline 5 & $65, \mathrm{~F}$ & Sellar/parasellar meningioma & 14 & 16 & 147 & NA & NA \\
\hline 6 & $21, \mathrm{M}$ & Temporal lobe cavernoma & 15 & 6 & 120 & NA & NA \\
\hline \multicolumn{8}{|l|}{ Group $2 \ddagger$} \\
\hline 7 & $30, \mathrm{M}$ & $\mathrm{TICH}$ & 4 & 15 & 75 & $\mathrm{R}>\mathrm{L}$ & $\mathrm{N}$ \\
\hline 8 & $41, \mathrm{~F}$ & $\mathrm{SAH}+\mathrm{ICH}+\mathrm{IVH}$ & 8 & 28 & 187 & $=$ & $\mathrm{Y}$ \\
\hline 9 & $46, \mathrm{~F}$ & $\mathrm{SAH}+\mathrm{IVH}$ & 8 & 20 & 170 & $=$ & $\mathrm{Y}$ \\
\hline 10 & $10, \mathrm{~F}$ & $\mathrm{ASDH}+\mathrm{DBS}$ & 6 & 22 & 58 & $=$ & $\mathrm{Y}$ \\
\hline 11 & $31, \mathrm{M}$ & $\mathrm{DAI}+$ focal contusion & 6 & 18 & 58 & $\mathrm{~L}>\mathrm{R}$ & $\mathrm{N}$ \\
\hline 12 & $43, \mathrm{M}$ & ASDH + bilateral contusions & 4 & 26 & 87 & $\mathrm{R}>\mathrm{L}$ & $\mathrm{Y}$ \\
\hline 13 & $29, \mathrm{M}$ & DBS & 7 & 14 & 116 & $=$ & $\mathrm{N}$ \\
\hline 14 & $8, \mathrm{M}$ & DBS & 7 & 14 & 79 & $=$ & $\mathrm{Y}$ \\
\hline 15 & $30, \mathrm{M}$ & DBS + deep TICH + contusion & 8 & 27 & 66 & $=$ & $\mathrm{Y}$ \\
\hline 16 & $47, \mathrm{M}$ & $\mathrm{TICH}$ & 8 & 20 & 76 & $=$ & $\mathrm{Y}$ \\
\hline 17 & $52, \mathrm{~F}$ & $\mathrm{TICH}$ & 6 & 26 & 124 & $\mathrm{R}>\mathrm{L}$ & $\mathrm{Y}$ \\
\hline 18 & $62, \mathrm{~F}$ & $\mathrm{SAH}+\mathrm{IVH}$ & 8 & 20 & 96 & $=$ & $\mathrm{N}$ \\
\hline 19 & $42, \mathrm{M}$ & DBS & 6 & 18 & 102 & $=$ & $\mathrm{N}$ \\
\hline 20 & $16, \mathrm{M}$ & DBS + bilateral contusions & 8 & 17 & 93 & $=$ & $\mathrm{N}$ \\
\hline
\end{tabular}

* AcoA = anterior communicating artery; ICAbif = internal carotid artery bifurcation; TICH = traumatic intracerebral hematoma; ICH = spontaneous intracerebral hematoma; $\mathrm{SAH}=$ subarachnoid hemorrhage; IVH = intraventricular hemorrhage; ASDH $=$ acute subdural hematoma; DBS = diffuse brain swelling; DAI = diffuse axonal injury; NA = not applicable. $\dagger$ Elective (post operative) monitoring group. $\$$ Emergency monitoring group. 


\begin{tabular}{|c|c|c|c|c|c|c|}
\hline \multicolumn{7}{|c|}{$\begin{array}{c}\text { Table } 2 \\
\text { Intracranial pressure monitoring data, complications and outcome* }\end{array}$} \\
\hline Case & $\begin{array}{c}\text { Mean ICP } \\
(\mathrm{mmHg}) / \text { range }\end{array}$ & $\begin{array}{c}\text { Mean CPP } \\
(\mathrm{mmHg}) / \text { range }\end{array}$ & $\begin{array}{c}\text { Plateau } \\
\text { waves }\end{array}$ & Days $\dagger$ & Complications & $\begin{array}{l}3 \text { mo. } \\
\text { GOS }\end{array}$ \\
\hline \multicolumn{7}{|l|}{ Group 1} \\
\hline 1 & $14.4 \pm 4.8(8-25)$ & $90.2 \pm 9.67(113-71)$ & $\mathrm{N}$ & 3 & Diabetes insipidus & 5 \\
\hline 2 & $14.1 \pm 3.6(8-20)$ & $91.2 \pm 8.7(112-82)$ & $\mathrm{N}$ & 3 & & 5 \\
\hline 3 & $14.6 \pm 5.1(9-23)$ & $92.9 \pm 4.7(100-85)$ & $\mathrm{N}$ & 2 & Gram neg. meningitis + DVT & 5 \\
\hline 4 & $11.6 \pm 3.5(7-19)$ & $97.5 \pm 7.5(115-86)$ & $\mathrm{N}$ & 2 & & 5 \\
\hline 5 & $23.2 \pm 5.1(16-28)$ & $62 \pm 61.8(147-12)$ & $\mathrm{N}$ & 1 & Acute tumor bed hemorrhage + catheter obstruction & 1 \\
\hline 6 & $8.9 \pm 2.2 \quad(6-12)$ & $92.3 \pm 12.4(120-80)$ & $\mathrm{N}$ & 2 & & 5 \\
\hline \multicolumn{7}{|l|}{ Group 2} \\
\hline 7 & $16.1 \pm 2.4(10-20)$ & $82.1 \pm 15.7(122-59)$ & $\mathrm{N}$ & 4 & Hypothalamic insufficiency & 1 \\
\hline 8 & $15.1 \pm 5.9(7-32)$ & $120 \pm 29.5(184-92)$ & $\mathrm{N}$ & 6 & Catheter obstruction + rebleeding & 2 \\
\hline 9 & $26.3 \pm 8.1(11-42)$ & $100 \pm 22.3(148-60)$ & $\mathrm{N}$ & 11 & $\mathrm{ARF}+\mathrm{PE}$ & 1 \\
\hline 10 & $24.9 \pm 7.1(16-35)$ & $40.1 \pm 17.2(62-13)$ & $\mathrm{Y}$ & 1 & Catheter obstruction & 1 \\
\hline 11 & $17.2 \pm 4.9(9-23)$ & $92.5 \pm 21.7(123-58)$ & $\mathrm{N}$ & 3 & MRSA sepsis & 3 \\
\hline 12 & $28.7 \pm 10.3(16-58)$ & $66.3 \pm 21.6(106-29)$ & $\mathrm{Y}$ & 3 & & 1 \\
\hline 13 & $18.7 \pm 8.3(5-38)$ & $96.2 \pm 15.7(136-60)$ & $\mathrm{N}$ & 6 & ARDS & 5 \\
\hline 14 & $21.5 \pm 6.0(14-30)$ & $70.8 \pm 11.2(91-56)$ & $\mathrm{N}$ & 1 & Pulmonar contusion & 1 \\
\hline 15 & $30.9 \pm 14.7(8-69)$ & $71.2 \pm 21.6(99-20)$ & $\mathrm{Y}$ & 7 & Nosocomial pneumonia & 1 \\
\hline 16 & $16.4 \pm 6.1(8-27)$ & $82.9 \pm 13.8(114-61)$ & $\mathrm{N}$ & 3 & & 5 \\
\hline 17 & $32.3 \pm 14.2(12-58)$ & $74.8 \pm 25.3(124-23)$ & $\mathrm{Y}$ & 2 & & 1 \\
\hline 18 & $20.3 \pm 5.6(12-32)$ & $113 \pm 21.5(161-77)$ & $\mathrm{N}$ & 7 & Nosocomial pneumonia & 3 \\
\hline 19 & $18.6 \pm 6.1(10-32)$ & $86.1 \pm 8.2(102-70)$ & $\mathrm{N}$ & 2 & & 5 \\
\hline 20 & $17.8 \pm 5.7(10-28)$ & $98.6 \pm 11.4(126-84)$ & $\mathrm{N}$ & 3 & & 5 \\
\hline
\end{tabular}

* GOS = Glasgow outcome scale at three months; DVT = deep vein thrombosis; PE = pulmonary embolism; ARF = acute renal failure; ARDS = adult respiratory distress syndrome; MRSA = methycillin resistant Staphylococcus aureus. $\dagger$ Total days of ICP monitoring.

In all patients in Group 1, the initial ICP was less than $20 \mathrm{mmHg}$, which is probably related to the fact that all of them were in an immediate postoperative period of surgeries that required a craniotomy, dural and cisternal opening and, eventually, ventricular drainage ${ }^{41}$. All of them had a good outcome, except for case $\mathrm{n}^{\circ} 5$ who died from complications of the primary surgical procedure (Table 2); three patients presented ICP peaks over $20 \mathrm{mmHg}$ which were successfully managed by CSF drainage only.

In Group 2, the initial ICP varied from 14 to $28 \mathrm{mmHg}$ (mean $20.4 \pm 4.8$ ). In this group, six out of eight patients with initial ICP of $20 \mathrm{mmHg}$, or over, had an unfavorable outcome while two out of four patients with initial ICP of less than $20 \mathrm{mmHg}$ died or were left vegetative, although it did not reach statistical significance $(\mathrm{p}=0.15)$.

In Group 2 the initial CPP varied from 58 to $187 \mathrm{mmHg}$ (mean 99.1 \pm 39.1 ). An initial CPP of over $70 \mathrm{mmHg}$ also did not correlate well with good outcome $(\mathrm{p}=0.61)$.

Mean ICP variations among patients in Group 2 correlated well with outcome. Patients with a GOS of 12 had a mean ICP of $24.5 \pm 6.4 \mathrm{mmHg}$ while patients with a GOS of $3-5$ had a mean ICP of $18.2 \pm 1.3 \mathrm{~mm} \mathrm{Hg}$ $(p=0.03)$. In contrast, the difference between CPP mean values in Group 2 for good and bad outcomes was not statistically significant $(\mathrm{p}=0.14)$.
A total of eight patients presented with neurological deterioration in the emergency monitoring group before ventriculostomy was instituted. That also had a good correlation with a bad outcome $(\mathrm{p}=0.02)$.

We were able to observe Lundberg plateau waves in four patients that died in this series $(p=0.06)$, all of them in Group 2 (Table 2).

\section{Complications}

No cases of overt ventricular infection were detected during the monitoring period. We decided not to search for catheter colonization, which is almost always present in patients kept with the device for prolonged times, usually more than 3-5 days. A febrile patient with white blood cell count alterations was always investigated in a broad context, which also included a CSF bacteriological study. One patient in Group 1 developed a Gram negative bacillus meningitis seven days after she had been discharged from the ICU and ten days after the intraventricular catheter had been removed; in this way, we could not attribute this complication to the ICP monitoring technique itself, also considering that she was in a postoperative period of a protracted surgery. 
Three patients $(15 \%)$ had a catheter obstruction, which was observed as an interruption of CSF outflow and disappearance of the ICP wave, that could not be managed by repositioning alone and required the removal of the original system. In one patient, we were able to place another catheter into the contralateral ventricle and maintain our protocol. In other two patients, we could not have it done after three attempts, so we decided to abandon the procedure. In both cases, the ICP readings before the detected obstruction were over $40 \mathrm{mmHg}$. The patients were in a shock state receiving vasopressor agents. Both died in a 24 hourperiod. In one of them (case $n^{\circ} 10$ ) the necropsy did not reveal any lesions that could be related to the catheter placement.

One out of three patients with subarachnoid hemorrhage (SAH) and associated intraventricular hemorrhage, experienced an episode of rebleeding on the third day. It has been already described as a potential complication of ventriculostomy in uncontrolled studies ${ }^{29}$.

No clinically significant intracranial hemorrhages due to the procedure were found in this study. The other complications noted in the patients of this series (Table 2) could not be linked to the ICP monitoring methodology, and were related to their basic diseases.

\section{Discussion}

ICP monitoring is recommended as a guideline in patients with severe head injury and an abnormal admission CT scan ${ }^{19,20,28,33,43}$. It is also appropriate for patients with severe head injury and a normal CT scan if at least two of the following features are noted at admission: age over 40 years, uni or bilateral motor posturing, systolic blood pressure $<90 \mathrm{~mm} \mathrm{Hg}^{19,20,28,32,33,43}$. Ventriculostomy with or without ICP monitoring is also recommended for patients with $\mathrm{SAH}$ and acute (obstructive) hydrocephalus, with data mainly derived from nonrandomized cohort studies and the advice that it may be associated with an increased rebleeding incidence ${ }^{15,29,36,42}$. In patients with spontaneous intracerebral hemorrhages (ICH), ICP management has been oriented based on ICP monitoring supported by anecdotal case series ${ }^{5,12,35,40}$. Although we could not find any formal guidelines concerning ICP monitoring after elective intracranial surgery, there are suggestions that it should be used liberally, specially for supratentorial lesions and when some risk factors for ICP elevation could be predicted $d^{6,10,22,31}$.

Those management protocols rely, at least in part, in a clear lack of specific medical treatments to protect patients from secondary injuries ${ }^{28}$. In that way, therapy has been based on surgical decompression of mass lesions, artificial ventilation and ICP monitoring with emphasis on CPP management ${ }^{3,19,37}$, although it has been recently challenged $d^{7,21,28}$, specifically for severe traumatic brain lesions.

In summary, there are current indications that ICP monitoring helps in early detection of mass lesions, can limit the indiscriminate use of therapies to control ICP, can reduce ICP and thus improve CPP, helps in determining prognosis and may improve outcome ${ }^{19,20}$. There is also a trend towards the indication for ICP monitoring in patients with ICH for basically the same reasons, although no controlled studies have been done so far. In patients with spontaneous SAH there are also some suggestions that intracranial hypertension may have a relationship to the duration and severity of vasospasm leading to conclusions that ICP monitoring could potentially detect and avoid this complication ${ }^{14,15}$. Regarding postoperative monitoring for supratentorial lesions, there are studies showing that ICP elevations can precede or, at least, parallel a deterioration event, leading to more prompt responses once it is detected and a theoretical improvement in outcome $\mathrm{e}^{6,10,22,45}$. Some reports suggest that ICP monitoring can also help and guide the nursery for all those patients, giving information on ICP status during frequent procedures such as head positioning, endotracheal tube suctioning, passive motion and so on $\mathrm{n}^{4,17,24,30}$.

Although we have seen in recent years a massive diffusion of refined techniques for ICP monitoring, with an increasing number of types and brands of monitors, different kinds of fiberoptic catheters and specific transducers for placement in variable locations inside the skull ${ }^{19}$, a ventricular catheter connected to an external strain gauge transducer remains the most accurate, cheaper, and reliable method for ICP monitoring ${ }^{19,20,33,43}$. It also offers the benefit of draining CSF in cases of intracranial hypertension and can be recalibrated when needed ${ }^{19,20,23,39}$. On the other side, it has the drawback of potential obstruction of the fluid couple and consequent loss of signal and inaccuracy, and has to be maintained at a fixed reference point to the patient's head to avoid erroneous reading $\mathrm{s}^{18,19,20,38}$. We have noted only a few cases of obstruction in our series that needed the replacement of the catheter, all of them in patients with severe intracranial hypertension. According to some reports, it typically occurs in patients with ICP over $40-50 \mathrm{mmHg}$ and has usually no adverse effects on outcome $\mathrm{e}^{19,20,41}$.

The major complications of intraventricular indwelling catheters are infection (sometimes reported as colonization, adding some confusion to its clinical significance) and hemorrhage, although they rarely 
become symptomatic ${ }^{18,19,20,38}$. The differences in incidence of complications from one method of ICP monitoring to another, particularly for $\mathrm{ICH}$, is probably multifactorial ${ }^{18,38}$. Undoubtedly, the need for multiple punctures raises this risk. Nonetheless, we could feel progressively more comfortable to reach even severely compressed ventricles, something that may seem rather difficult for the unskilled one. In that way, no clinically significant hematomas were noted in our study group.

Regarding intracranial plateau waves, we could observe them, typically, in patients with uncontrollable intracranial hypertension. Although some have noted that their presence per se do not increase the incidence of unfavorable outcomes ${ }^{9}$, they denote a depletion in the pressure-volume reserve and can be used along ICP data to construct a dynamic index of prognosis ${ }^{8}$. All of our patients with plateau waves died, with a discreet statistical relation towards bad outcome, probably because of the study population size.

Although we presented a small series, we could find a strong correlation between mean ICP and outcome, while mean CPP did not follow that correlation. Juul et al. ${ }^{21}$ have suggested recently that protocols aiming at increasing CPP but not attempting to reduce ICP are unacceptable. Marshall ${ }^{28}$, in a broad review of head injury management, says that CPP should be kept under acceptable values but there is little evidence that raising it produces any definable benefit on final result. $\mathrm{Cruz}^{7}$ adds that "normal-toincreased CPP holds absolutely no correlation with cerebral oxygen metabolism (both oxygen extraction and consumption), thus ruling out any beneficial effect of normal-to-increased CPP levels". Our option to not deliberately elevate CPP seems reasonable in this scenario.

The time course of deterioration, specifically with regards to ICP levels, has been a controversial subject. There are strong data suggesting that neurological worsening correlates well with unfavorable outcome ${ }^{21}$, as we could also observe, but few reports have shown that intracranial hypertension clearly precedes these events. Nevertheless, there is some potential for prediction and, thus, avoidance of deterioration both in elective and emergency situations.

In view of all facts, the Brazilian Neurosurgical Society has recently published and recommended a guideline somewhat similar to the one developed by the Brain Trauma Foundation in cooperation with the American Association of Neurological Surgeons regarding the general management and ICP monitoring indications for patients with severe head injury ${ }^{2}$. There are few reports, though, that focus on ICP monitoring protocols in the Brazilian literature, all of them belonging to huge reference centers ${ }^{2,10,11}$. Most smaller centers in our Country still deal with those patients in a somewhat anarchic way, without evident criteria for utilization of usual therapeutic tools such as mannitol and hyperventilation, no measurement of what is done, no clear-cut endpoint for them and even with the usage of outdated therapies such as corticosteroids and dehydration. Ghajar et al. ${ }^{16}$, in a recent survey of critical care management of severely head-injured patients in America stressed the need to establish guidelines that could be followed not only by reference trauma centers, but also by units that treat fewer patients, aiming at improving the standard of care. They add that it should be moderated by practical and financial considerations in order to broaden its range. ICP monitoring by a fluid coupled catheter connected to an external strain gauge transducer suits our needs to adhere to those recommendations since it is a inexpensive, reliable and easy method with few complications that most of the time do not interfere with results.

\section{Conclusions}

Routine intracranial pressure monitoring with intraventricular indwelling catheter connected to an external strain gauge transducer is a safe and reproducible method of ICP monitoring even with limited resources circumstances. It proved to be easily applied, helped us to choose and modulate therapies and provided hints that clarified the prognosis of the patients, at a definitely low cost, since we could apply the equipment already available at our institution. Further, we have had few complications related to the method with no interference on the final outcome. We suggest it should be used routinely in centers that care for patients with severe traumatic and spontaneous brain injuries and also after elective surgeries that require brain retraction, and can not afford to expensive apparatuses. The main purpose, after all, is to optimize and try to improve outcome.

\section{References}

1. ALLEN CH, WARD JD: An evidence-based approach to management of increased intracranial pressure. Crit Care Clin 14:485-95, 1998.

2. ANDRADE AF, CIQUINI JR O, FIGUEIREDO EG, BROCK RS, MARINO JR R: Diretrizes do atendimento ao paciente com traumatismo craniencefálico. Arq Bras Neurocir 18(Edição Especial):131-76, 1999.

3. BIESTRO A, BARRIOS E, BARAIBAR J, PUPPO C LUPANO D, CANCELA M, BOROVICH B, POUSO J: 
Use of vasopressors to raise cerebral perfusion pressure in head injured patients. Acta Neurochir Suppl (Wien) 71:5-9, 1998.

4. BRIMIOULLE S, MORAINE JJ, NORRENBERG D, KAHN RJ: Effects of positioning and exercise on intracranial pressure in a neurosurgical intensive care unit. Phys Ther 77:1682-89, 1997.

5. BRODERICK JP, ADAMS HP J, BARSAN W, FEINBERG W, FELDMANN E, GROTTA J, KASE C, KRIEGER D, MAYBERG M, TILLEY B, ZABRAMSKI JM, ZUCCARELLO M: Guidelines for the management of spontaneous intracerebral hemorrhage. Stroke 30:905-15, 1999.

6. CONSTANTINI S, COTEV S, RAPPAPORT ZH, POMERANZ S, SHALIT MN: Intracranial pressure monitoring after elective intracranial surgery. A retrospective study of 514 consecutive patients. J Neurosurg 69:540-4, 1988.

7. CRUZ J: Current international trends in severe acute brain trauma. Arq Neuropsiquiatr (São Paulo) 58:6427, 2000.

8. CZOSNYKA M, GUAZZO E, WHITEHOUSE M, SMIELEWSKI P, CZOSNYKA Z, KIRKPATRICK P, PIECHNIK S, PICKARD JD: Significance of intracranial pressure waveform analysis after head injury. Acta Neurochir (Wien) 138:531-41, 1996.

9. CZOSNYKA M, SMIELEWSKI P, PIECHNIK S, SCHMIDT EA, AL-RAWI PG, KIRKPATRICK PJ, PICKARD JD: Hemodynamic characterization of intracranial pressure plateau waves in head-injured patients. J Neurosurg 91:11-9, 1999.

10. AZEVEDO FILHO HR, ADAMS CB, KERR J: Intracranial compliance during the post-operative period after surgery for intracranial aneurysms. Arq Neuropsiquiatr (São Paulo) 37:250-4, 1979.

11. FALCAO AL, DANTAS FILHO VP, SARDINHA LA, QUAGLIATO EM, DRAGOSAVAC D, ARAÚJO $S$, TERZI RG: Highlighting intracranial pressure monitoring in patients with severe acute brain trauma. Arq Neuropsiquiatr (São Paulo) 53:390-4, 1995.

12. FERNANDES HM, SIDDIQUE S, BANISTER K, CHAMBERS I, WOOLDRIDGE T, GREGSON B, MENDELOW AD: Continuous monitoring of ICP and CPP following $\mathrm{ICH}$ and its relationship to clinical, radiological, and surgical parameters. Acta Neurochir (Suppl) 76: 463-6, 2000.

13. FRIEDMAN WA, VRIES JK: Percutaneous tunnel ventriculostomy. Summary of 100 procedures. J Neurosurg 53:662-5, 1980.

14. FUKUHARA T, DOUVILLE CM, ELIOTT JP, NEWELL DW, WINN HR: Relationship between intracranial pressure and development of vasospasm after aneurysmal subarachnoid hemorrhage. Neurol Med Chir (Tokyo) 38:710-5, 1998.

15. GAMBARDELLA G, DE BLASI F, CARUSO G, ZEMA A, TURIANO F, COLLUFIO D: Intracranial pressure, cerebral perfusion pressure, and SPECT in the management of patients with $\mathrm{SAH}$ Hunt and Hess grades I-II. Acta Neurochir Suppl (Wien)71:215-8, 1998.

16. GHAJAR J, HARIRI RJ, NARAYAN RK, IACONO LA, FIRLIK K, PATTERSON RH: Survey of critical care management of comatose, head-injured patients in the United States. Crit Care Med 24:897-8, 1995.

17. GONZALEZ-ARIAS SM, GOLDBERG ML, BAUMGARTNER R, HOOPES D, RUBEN B: Analysis of the effect of kinetic therapy on intracranial pressure in comatose patients. Neurosurgery 13:654-6, 1983.
18. GUYOT LL, DOWLING C, DIAZ FG, MICHAEL DB: Cerebral monitoring devices: analysis of complications. Acta Neurochir Suppl (Wien)71:47-49, 1998.

19. Joint Section on Trauma and Critical Care of the American Association of Neurological Surgeons and the Brain Trauma Foundation: Guidelines for the Management of Severe Head Injury. Park Ridge, III: American Association of Neurological Surgeons, 1995.

20. Joint Section on Trauma and Critical Care of the American Association of Neurological Surgeons and the Brain Trauma Foundation: Management and Prognosis of Severe Traumatic Brain Injury. Park Ridge, III: American Association of Neurological Surgeons, 2000.

21. JUUL N, MORRIS G, MARSHALL SB. The executive committee of the international selfotel trial. Marshall LF: Intracranial hypertension and cerebral perfusion pressure: influence on neurological deterioration and outcome in severe head injury. J Neurosurg 92:1-6, 2000.

22. KAYE AH, BROWNBILL D: Postoperative intracranial pressure in patients operated on for cerebral aneurysms following subarachnoid hemorrhage. J Neurosurg 54:726-32, 1981.

23. KERR ME, MARION D, SEREIKA SM, WEBER BB, ORNDOFF PA, HENKER R, WILBERGER J: The effect of cerebrospinal fluid drainage on cerebral perfusion in traumatic brain injured adults. J Neurosurg Anesthesiol 12:324-33, 2000.

24. KOCH SM, FOGARTY S, SIGNORINO C, PARMLEY L, MEHLHORN U: Effect of passive range of motion on intracranial pressure in neurosurgical patients. J Crit Care 11:176-9, 1996.

25. LUERSSEN TG: Intracranial pressure: current status in monitoring and management. Semin Pediatr Neurol 4:146-55, 1997.

26. MAAS AI, DEARDEN M, TEASDALE GM, BRAAKMAN $R$, COHADON F, IANNOTTI F, KARIMI A, LAPIERRE F, MURRAY G, OHMAN J, PERSSON L, SERVADEI F, STOCCHETTI N, UNTERBERG A: EBIC-guidelines for management of severe head injury in adults. European Brain Injury Consortium. Acta Neurochir (Wien) 139:286-94, 1997.

27. MARMAROU A, ANDERSON RL, WARD JD, CHOI SC, YOUNG HF, EISENBERG HM, FOULKES MA, MARSHALL LF, JANE JA: Impact of ICP instability and hypotension on outcome in patients with severe head trauma. J Neurosurg 75:S59-S66, 1991.

28. MARSHALL LF: Head injury: recent past, present, and future. Neurosurgery 47:546-61, 2000.

29. MAYBERG MR, BATJER HH, DACEY R, DIRINGER M, HALEY EC, HEROS RC, STERNAU LL,TORNER J, ADAMS JR HP, FEINBERG W: Guidelines for the management of aneurysmal subarachnoid hemorrhage. A statement for healthcare professionals from a special writing group of the Stroke Council, American Heart Association. Stroke 25:2315-28, 1994.

30. MITCHELL PH, OZUNA J, LIPE HP: Moving the patient in bed: effects on intracranial pressure. Nurs Res 30 : 212-8, 1981.

31. NOTERMAN J, BERRE J, VANDESTEENE A, BROTCHI J: Le monitorage de la pression intracranienne (P.I.C.) durant la phase postoperatoire des anevrismes. Neurochirurgie 34:161-3, 1988.

32. O'SULLIVAN MG, STATHAM PF, JONES PA, MILLER JD, DEARDEN NM, PIPER IR, ANDERSON SI, HOUSLEY A, ANDREWS PJ, MIDGLEY S, CORRIE J, 
TOCHER JI, SELLAR R: Role of intracranial pressure monitoring in severely head-injured patients without signs of intracranial hypertension on initial computerized tomography. J Neurosurg 80:46-50, 1994.

33. PROCACCIO F, STOCCHETTIN, CITERIO G, BERARDINO M, BERETTA L, DELLA CORTE F, D'AVELLA D, BRAMBILLA GL, DELFINI R, SERVADEI F, TOMEI G: Guidelines for the treatment of adults with severe head trauma (part I). Initial assessment; evaluation and pre-hospital treatment; current criteria for hospital admission; systemic and cerebral monitoring. J Neurosurg Sci 44:1-10, 2000.

34. RESNICK DK, MARION DW, CARLIER P: Outcome analysis of patients with severe head injuries and prolonged intracranial hypertension. J Trauma 42:1108-11, 1997.

35. ROPPER AH, KING RB: Intracranial pressure monitoring in comatose patients with cerebral hemorrhage. Arch Neurol 41:725-8, 1984.

36. RORDORF G, OGILVY CS, GRESS DR, CROWELL $\mathrm{RM}, \mathrm{CHOI}$ IS: Patients in poor neurological condition after subarachnoid hemorrhage: early management and long-term outcome. Acta Neurochir (Wien) 139: 1143-51, 1997.

37. ROSNER MJ, ROSNER SD, JOHOSON AH: Cerebral perfusion pressure: management protocol and clinical results. J Neurosurg 83:949-62, 1995.

38. ROSSI S, BUZZI F, PAPARELLA A, MAININI P, STOCCHETTI N: Complications and safety associated with ICP monitoring: a study of 542 patients. Acta Neurochir Suppl (Wien) 71:91-3,1998.

39. SCHICKNER DJ, YOUNG RF: Intracranial pressure monitoring: fiberoptic monitor compared with the ventricular catheter. Surg Neurol 37:251-4, 1992.
40. SEESTEDT RC, FRANKEL MR: Intracerebral hemorrhage. Curr Treat Options Neurol 1:127-37, 1999.

41. SHIELDS CB, MCGRAW CP, GARRETSON HD: Accurate intracranial pressure monitoring: technical note. Neurosurgery 14:592-3, 1984.

42. SUZUKI M, OTAWARA Y, DOI M, OGASAWARA K, OGAWA A: Neurological grades of patients with poorgrade subarachnoid hemorrhage improve after shortterm pretreatment. Neurosurgery 47:1098-104, 2000.

43. The Brain Trauma Foundation. The American Association of Neurological Surgeons. The Joint Section on Neurotrauma and Critical Care. Indications for intracranial pressure monitoring. J Neurotrauma $17: 479-91,2000$

44. VUKIC M, NEGOWETIC L, KOVAC D, GHAJAR J, GLAVIC Z, GOPCEVIC A: The effect of implementation of guidelines for the management of severe head injury on patient treatment and outcome. Acta Neurochir (Wien) 141:1203-8, 1999.

45. WHITTLE IR, VISWANATHAN R: Acute intraoperative brain herniation during elective neurosurgery: pathophysiology and management considerations. J Neurol Neurosurg Psychiatry 61:584-90, 1996.

Original recebido em novembro de 2001

Aceito para publicação em março de 2002

\section{Endereço para correspondência:}

Andrei Ferraz

Rua 17 de Outubro, 239

CEP 27600-000 - Valença, RJ

E-mail:andrei.ferraz@uol.com.br 